\title{
Solution of Water Distribution Networks Design with Evolutionary Optimization Techniques
}

\author{
Büşra Seval Doğan ${ }^{1 *}$, Tahir Sağ ${ }^{2}$ \\ ${ }^{1 *}$ Selçuk University, Institute of Science, Department of Computer Engineering, Konya, Turkey, (ORCID: 0000-0002-5969-2860), doganbusraseval@gmail.com \\ ${ }^{2}$ Selçuk University, Faculty of Technology, Department of Computer Engineering, Konya, Turkey, (ORCID: 0000-0001-8266-7148), tahirsag@,selcuk.edu.tr
}

(1st International Conference on Applied Engineering and Natural Sciences ICAENS 2021, November 1-3, 2021)

(DOI: 10.31590/ejosat.1009768)

ATIF/REFERENCE: Doğan, B.S. \& Sağ, T. (2021). Solution of Water Distribution Networks Design with Evolutionary Optimization Techniques. European Journal of Science and Technology, (28), 638-642.

\begin{abstract}
Due to its vital importance, water is known as one of the sources of both civilization and social development. All civilizations have established their settlements near water sources. However, since the work of taking water from its source and transmitting it to the users in the settlements, that is, the establishment of water networks, is a costly process, it has been one of the most important Engineering problems from the past to the present. In this study, a comprehensive literature review on evolutionary optimization algorithms used in solving water distribution network designs is presented. First, the explanation of the design problem, the decision variables, and its mathematical definition are emphasized. Then, the studies on the subject so far are examined chronologically. Finally, the results obtained from the findings are interpreted and the advantages and disadvantages of the methods put forward for the solution of the problem are revealed. In addition, determinations are made for future studies.
\end{abstract}

Keywords: Water distribution networks, evolutionary optimization, metaheuristics, combinatorial optimization, WDN benchmarks.

\section{Su Dağıtım Şebekeleri Tasarımının Evrimsel Optimizasyon Teknikleriyle Çözümü}

$\ddot{O} \mathbf{z}$

Yaşamsal önemi nedeniyle su, hem uygarlığın hem de toplumsal gelişmenin kaynaklarından biri olarak bilinmektedir. Bütün medeniyetler yerleşimlerini su kaynaklarının yakınına kurmuşlardır. Ancak yerleşim yerlerinde suyun kaynağından alınarak kullanıcılara iletilmesi, yani su şebekelerinin kurulması işi maliyetli bir süreç olduğundan, geçmişten günümüze en önemli mühendislik problemlerinden biri olmuştur. Bu çalışmada, su dağıtım şebekesi tasarımlarının çözümünde kullanılan evrimsel optimizasyon algoritmaları hakkında kapsamlı bir literatür taraması sunulmaktadır. İlk olarak tasarım probleminin açıklanması, karar değişkenleri ve matematiksel tanımı üzerinde durulmuştur. Daha sonra konuyla ilgili bugüne kadar yapılan çalışmalar kronolojik olarak incelenmiştir. Son olarak, bulgulardan elde edilen sonuçlar yorumlanarak problemin çözümü için ileri sürülen yöntemlerin avantaj ve dezavantajları ortaya konulmuştur. Ayrıca ileride yapılacak çalışmalar için tespitler yapılmaktadır.

Anahtar Kelimeler: Su dağıtım şebekeleri, evrimsel optimizasyon, meta-sezgisel, kombinatoryal optimizasyon, WDN kıyaslamaları.

\footnotetext{
* Corresponding Author: doganbusraseval@gmail.com
} 


\section{Introduction}

Water Distribution Networks (WDNs), which ensure that water is taken from the source and transmitted to the settlements, is an important design problem, especially in the field of civil engineering, from the past to the present. Because, in addition to the high cost of establishing WDNs, some constraints that should be followed in water distribution networks make it difficult to design networks. Some of these constraints can be listed in three items: (i) the multiplicity of non-linear expressions used in the calculation of pipe diameters, (ii) the necessity to keep the velocity and pressure values in the network within certain ranges, and (iii) the wide selection range seen in the types and diameters of the pipes produced.

These justifications require cost optimization for designing a new WDN or expanding an existing WDN. In this regard, many studies have been carried out on the cost optimization of WDNs since the 1960s. Although linear [1,2,3] and nonlinear [4] programming methods were used in this field in the early days, metaheuristic optimization methods started to be used because they were insufficient over time. It has been seen that researchers have been able to reach the global optimum result by making fewer evaluations in the search space with metaheuristic optimization methods compared to traditional methods.

Examining the related works in the literature, the same test networks called Benchmark WDN problems have been used in almost all of them. These studies focus only on cost optimization of the network and the problem addressed is designed as a singleobjective optimization problem. Many single-objective metaheuristic optimization algorithms were adapted to the problem and used to find the desired cost value. Considering the results of these studies, it can be concluded that the optimum cost values obtained by single-objective metaheuristics are quite close to each other, and method changes should be made in order to obtain better results.

The rest of the paper is organized as follows. In the concept of material and method, section II describes the features of WDNs, the mathematical definition of the design problem, and benchmark networks used in literature. Then, evolutionary optimization algorithms are briefly explained in section III. The related works on WDNs are given in section IV. Finally, concluding remarks and possible future works are provided in Section IV.

\section{Material and Method}

\subsection{Design Features of WDNs}

For a WDN system to be economical and close to the ideal system, it must have the following features [5].

$\checkmark$ Consisting of independent pressure zones of the network according to the recommended maximum and minimum pressure limits,

$\checkmark$ Providing the lowest pressure specified in the specifications to the users at every point of the system,

$\checkmark$ Providing as regular pressure as possible for a pressure zone and pressure variations not more than $\pm 20 \%$,

$\checkmark$ Providing water flow from different directions by arranging the network as closed eyes,

$\checkmark$ Establishing connections that can be used between regions for emergencies,

$e-I S S N: 2148-2683$ $\checkmark \quad$ Preferring materials and joining elements that will prevent corrosion and crusting,

$\checkmark$ Designing the relevant network in a way that will enable the detection of leaks that may occur in the network,

$\checkmark$ Availability of sufficient number of valves and evacuation equipment for easy operation of the business,

$\checkmark$ The low number of network elements that require frequent maintenance, especially underground.

$\checkmark$ Designing all elements in the network (pipe, connection equipment, etc.) to be resistant to the maximum pressures recommended in the regulation.

\subsubsection{Calculation Features of WDNs}

First, the method by which the hydraulic calculations in the networks will be made is determined. The most used methods are Hardy-Cross and the dead spots method. Network hydraulic calculations are made using the Dead Spots Method in Turkey. According to this method, it is thought that water comes from two branches in a network system and that these incoming waters are distributed to the users and end at one point. This point is called the dead point. The dead point, which is thought of as an imaginary point, does not actually exist. In this method, the sum of the load losses of the currents coming from the two branches should be equal. With this method, the network consisting of closed eyes is transformed into a branch system and hydraulic calculations are made easier. In the Hardy Cross method, the water to be distributed to the users is distributed from the node points, unlike the dead points method. In the Hardy-Cross method, the total flow rate entering the network and the total flow output should be equal.

The types of WDNs are depicted in Fig. 1, which are consist of branch system, branch-shaped network system, and closed network system.

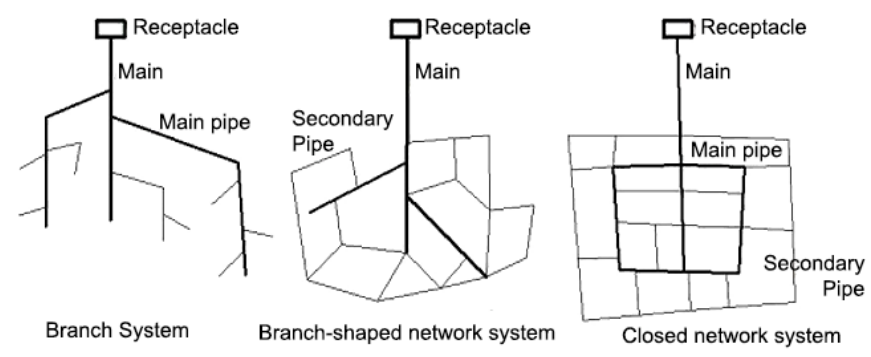

Fig. 1. Types of WDNs [25]

\subsection{Optimum Design of WDNs}

The objective function used to minimize the pipe diameter cost is as in Eq (1).

$$
Z=\sum_{i=1}^{M} C\left(D_{i}\right)-L_{i}+\delta
$$

where $\mathrm{Z}$ is the objective function, $\mathrm{M}$ is the number of pipes, $D_{i}$ is the diameter of ith pipe, $L_{i}$ is the length of ith pipe, and $\delta$ represents the total penalty cost calculated for any solution. The $\delta$ value consists of three parts (pressure $\mathrm{P}$, speed V, energy constraint $\varepsilon$ ) as shown in Eq (2).

$$
\left.\left.\delta=\left[\sum_{i=1}^{N} H\left(P_{\min }-P_{i}\right)\right] \varepsilon_{p}\left(P_{\min }-P_{i}\right)\right]+\left[\sum_{i=1}^{M} n V_{i}\right) \varepsilon_{r}\right]+\left[\sum_{a=1}^{K} \gamma_{a} \mid \cdot \varepsilon_{\gamma}\right]
$$

If the speed limit exceeds the limit values, the values of the penalty function are shown in Eq (3). 


$$
\eta\left(V_{i}\right)=\left\{\begin{array}{cc}
0 & V_{\min } \leq V_{i} \leq V_{\max } \\
\mu / V_{i} & V_{i}<V_{\min } \\
\mu . V_{I} & V_{i}>V_{\max }
\end{array}\right\}
$$

The steps to implement the objective function of a general network problem are as follows:

$\checkmark$ Calculation of unit pipe cost values according to pipe diameters

$\checkmark$ Obtaining the total pipe cost of the system

$\checkmark \quad$ Making hydraulic calculations of the system and obtaining pressure values

$\checkmark$ Calculation of penalty cost value for pressure

$\checkmark$ Calculation of penalty cost for energy constraint

$\checkmark$ Calculation of the total cost value.

\subsection{Test Networks used in Literature}

Test networks, which are called benchmark networks in the literature, are frequently used by researchers. The most wellknown examples of these are the Alperovits and Shamir grid, the Hanoi city networks, and the New York grid.

Alperovits and Shamir Network: This network is an imaginary network of 8 pipes created by Alperovits and Shamir [1] to optimize cost. Later, this imaginary network became a test network and was used by many researchers. It consists of 1 water reservoir, 6 nodes, and 8 pipes. Each pipe is 1,000 m long.

Hanoi City Network: The Hanoi network was used by many researchers and become a test network. It consists of 34 pipes, 31 nodes, and 1 weld. The minimum pressure value in the system is determined as $30 \mathrm{~m}$.

New York City Network: This network was first studied by Schake and Lai [6]. Later, like other networks, it was used by many researchers and became a test network. It consists of 21 pipes, 20 nodes, and 1 chamber. The network was later rehabilitated because the desired pressure value could not be achieved at some points. It differs from other networks as it is a rehabilitation project.

\section{Evolutionary Optimization Algorithms}

It is aimed to maximize or minimize one or more objectives created with decision variables that define the problems for the solution of problems frequently encountered in production, planning, design and many engineering fields. However, realworld optimization problems often involve multiple objectives that have to be met simultaneously. These problems can be solved deterministically regardless of the number of objectives but reaching the global optimum may cause high time and resource consumption in proportion to the complexity of the problem under consideration. At this point, it is known that evolutionary algorithms are used successfully on problems that cannot be modelled deterministically or where precise results cannot be obtained within reasonable time with mathematical methods.

An optimization problem is formally defined as Eq. (4).

$$
\begin{gathered}
\text { Maximize/Minimize } \\
y=f(x) \\
\text { Subject to } g(x)=\left\{g_{1}(x), g_{2}(x), \ldots, g_{J}(x)\right\} \leq 0 \\
h(x)=\left\{h_{1}(x), h_{2}(x), \ldots, h_{K}(x)\right\}=0 \\
\text { where } x=\left\{x_{1}, x_{2}, \ldots, x_{N}\right\} \in X \\
y=\left\{y_{1}, y_{2}, \ldots, y_{N}\right\} \in Y
\end{gathered}
$$

where $\mathrm{x}$ is the variable vector and $\mathrm{X}$ shows the variable space. $\mathrm{y}$ is the objective functions and $\mathrm{Y}$ is the objective space. $\mathrm{g}(\mathrm{x})$ is a vector of the inequality constraint and $\mathrm{h}(\mathrm{x})$ is a vector of the equality constraints.

Evolutionary algorithms do not guarantee to reach the global optimum due to their stochastic operating characteristics, but they often iteratively converge to an acceptable optimal solution, avoiding time and resource consumption. These algorithms create an analogy between the search space in the optimization problem and the heuristic approaches of living things to real-life problems. In other words, evolutionary algorithms are meta-heuristic techniques developed by being inspired by the individual or collective behaviors of living things in the face of complex tasks, evolutionary processes in nature, and physical or chemical reactions. Due to the wide application area and the existence of a wide variety of problems, this field of study continues to maintain its popularity in the literature for years.

In literature, continuous optimization takes up a larger place in terms of problem type, but real-world engineering problems also include many parameters that are discrete in nature. WDN problems are in this category of optimization problems, which are called combinatorial optimization. In continuous optimization, the decision variables can take any value in the search space while the problem of arranging, grouping, ordering, or selecting discrete quantities optimally are take predefined values in the search space $[26,27]$. Determining the types, diameters, and sequences of a large number of pipes to be used in the system are strictly considered a combinatorial optimization problem.

These algorithms are generally grouped under three main categories: (i) evolutionary algorithms, (ii) swarm-intelligence algorithms, and (iii) physics-based algorithms. Evolutionary algorithms are population-based intelligent optimization methods that use mechanisms inspired by biological evolution. Genetic Algorithm (GA) [8] and Differential Evolution Algorithm (DE) [19] are the most well-known algorithms in this category. Although Swarm Intelligence algorithms are singularly simple agents in nature, they are techniques developed by being inspired by the collective behavior of centralized and self-organizing creatures such as birds, fishes, and insect colonies that can perform complex tasks collectively. Particle Swarm Optimization (PSO) [16], Artificial Bee Colony (ABC) [22], Ant Colony Optimization (ACO) [32], and Cuckoo Search (CS) [33] algorithms are the most studied algorithms in this category. Physics-based algorithms are meta-heuristic techniques that try to converge to the global optimum by imitating the physical rules in the search space. Some of the algorithms in this category can be listed as Simulated Annealing (SA) [31], Gravitational Search Algorithm (GSA) [30], Water Evaporation Optimization [28], and Thermal Exchange Optimization [29].

However, evolutionary optimization algorithms are classified into two groups as single-objective and multi-objective optimization algorithms according to the number of objectives of the problems they are applied to.

\section{Related Works}

The works on the design of WDNs started in the 1960s. With the developing technology, it has become easier to design the network that provides the necessary constraints for the network design and gives a low-cost value. The first studies on network design were made with traditional optimization methods. The 
study by Schake and Lai [6] is one of the first studies in this field. Researchers have investigated the optimum value of the cost of the New York grid. Researchers have done this by using the traditional optimization method, Dynamic Programming.

The study conducted by Alperovits and Shamir [1] in the following years is one of the most followed studies in the literature. The researchers calculated the global optimum value of an imaginary network consisting of 8 pipes using the Linear Programming method. The 8-pipe imaginary network created in this study became the test network, and the results of all subsequent studies using this test network were compared with the results of this study. The Linear Programming method was also used by Quindry and Liebman [2] to perform cost optimization on the New York grid. As a result of their study, the lowest cost value obtained in previous studies on this network has been reduced by $13 \%$. In the study conducted by Kessler and Shamir [3], the objective function of the Linear Programming method and the flow distribution of the pipes in the network were updated. While the cost value on the working network was higher before the Linear Programming method was updated, a lower cost value was obtained in the study after the Linear Programming method was updated. On the other hand, the steady-state simulation, reliability, and optimization model were combined in a single study by $\mathrm{Su}$ et al [4]. In their study, the nonlinear programming method was used as a method.

Traditional optimization methods such as linear and nonlinear programming were unsuccessful in the studies carried out until the 1990s. Since 1990, researchers have started to use metaheuristic methods. In 1990, Monbaliu et al. developed a rulebased algorithm, different from the previous studies, and tried to achieve the global optimum in network design by using this method. In the algorithm they developed first the smallest diameter is assigned to all pipes in the network and the pressure values in the system are calculated. If sufficient pressure cannot be provided at any point in the system, the diameter of the pipe with the greatest head loss is increased to an upper diameter value. This process is continued until the desired pressure condition is achieved at all points in the system. However, the effectiveness of this method has not been proven [7].

The Genetic Algorithm (GA), which has many applications in the literature, was first used by Goldberg in 1989 for network optimization. For the first time, the use of GA has attracted great attention. GA was used in many studies after this study. One of these studies is the study by Simpson et al [8]. They compared the results of their work with the GA with the results of their previous work using nonlinear programming methods. They reached the global optimum result by evaluating in fewer search spaces with GA. In the following years, Dandy et al [9] developed the GA method and suggested that gray coding would be more successful than binary coding in expressing decision variables. Their method was tested on the New York network and was more successful than the raw GA. The GA method was also used by Savic and Walters [10] for network design. They also created a computer model called GANET. Alperovits and Shamir, Hanoi and New York networks were used as networks for cost optimization. Wu and Simpson [11] developed the GA method to make it applicable in large networks. They tested it on the New York and Morocco networks and obtained more successful results than the raw Genetic Algorithm model. Afshar [12] tried to obtain the global optimum value by using the alternative penalty functions with the GA method on Hanoi and New York networks. GA was used by Ozdaglar et al [13] for the optimization of complex drinking water e-ISSN: 2148-2683 distribution systems. İzmir Atatürk Organized Industrial Zone (IAOSB) drinking water distribution network is solved with a program called SUGANET, which designs with genetic algorithm, and the results are examined in terms of economy and hydraulics. On the other hand, the GA was developed by Kadu et al [14] in such a way as to reduce the search space, and cost optimization was performed on Hanoi network and different sample networks. Effective results have been obtained in largesized networks.

In the following years, cost optimization was made by Conceicao Cunha and Ribeiro [15] using Tabu Search method. The results were close to the previously used GA and SA algorithm results. PSO was used for the first time for cost optimization by Suribabu and Neelakantan [16]. Hanoi and Alperovits and Shamir were used as test networks. They reported that successful results were obtained with fewer iterations compared to the studies in which the GA and SA algorithms were used. Montalvo et al [17] made PSO suitable for the selection of discrete pipe diameters in networks. They worked on the New York and Hanoi networks. They drew attention to the speed of the solution of the algorithm and the ease of application of the problems. Ezzeldin et al [18] used PSO to include different velocity and pressure values in the WDN optimization problem and applied them on the Alperovits and Shamir networks.

Suribabu [19] performed cost optimization on sample networks of Hanoi, Alperovits, and Shamir, New York, and the two-chamber networks. DE was used as the method. They stated that more successful results were obtained with the method used compared to GA. Vasan and Simonovic [20] made cost optimization by integrating the DE algorithm into the EPANET program on Hanoi and New York networks. Although low cost was not achieved, successful results were obtained. Zheng et al [21] adjusted the algorithm to reduce the effect of the parameters used in DE on the solution. They have achieved successful results on the New York and Hanoi networks.

Cost optimization was made by Yilmaz [22] on a part of the WDN of Akyurt district of Ankara. He used ABC, GA, and PSO algorithms in his study and although $\mathrm{ABC}$ algorithm was used for the first time in this field, it reached hopeful results as much as other approaches. The performances of metaheuristic optimization methods were investigated by Zeybekoğlu [23] in 2017 on a simple water distribution network using Cuckoo and Firefly Algorithms. When the results of the study were compared with the results in the literature, they concluded that the Cuckoo algorithm was more successful. CS was used by Noori [24] to obtain the closest solution to the time-cost-quality trade-off problem in construction projects. With the CS search algorithm, the best or closest results were reached in the shortest time. The solutions obtained with the results of the study were compared with other algorithm solutions in the literature.

\section{Conclusions and Recommendations}

In academic research on the optimal design of water distribution networks, linear programming was accepted as a popular method in the early days and was applied by many researchers. Later, it is seen that studies using traditional optimization methods such as dynamic programming and nonlinear programming are included in the literature.

Researchers have started to use metaheuristic optimization methods, considering that traditional optimization methods 
(Linear \& Non-Linear Programming) were insufficient in the studies carried out until the 1990s. Many single-objective metaheuristic optimization algorithms such as Genetic Algorithm, Simulation Annealing, Differential Evolution, Particle Swarm Optimization, Harmony Search, and many others have been proposed for this purpose and it has been seen that more successful results can be achieved than traditional optimization methods.

When the previous studies are examined, it is observed that the obtained cost value is quite close to each other, although the single-objective optimization algorithms used are different. It can be deduced that trying to solve the WDN problem only in the context of cost minimization does not always provide satisfactory results.

In further works, the WDNs problem can be handled as a multi-objective optimization problem. The cost function and the constraints of the problem can be accepted as objective functions conflicting with each other. Thus, thanks to the perspective provided by evolutionary multi-objective optimization algorithms, more efficient and accurate results can be calculated compared to single-objective optimization.

\section{References}

[1] Alperovits E. \& Shamir U. (1977), "Design of optimal water distribution systems," Water Resources Research, 13(6), 885900.

[2] Quindry G. E., Liebman J. C., \& Brill E. D. (1981), "Optimization of looped water distribution systems," Journal of the Environmental Engineering Division, 107(4), 665-679.

[3] Kessler A. and Shamir U. (1989), "Analysis of the linear programming gradient method for optimal design of water supply networks," Water Resources Research, 25(7), 14691480.

[4] Su Y.C., Mays L. W., Duan N. \& Lansey K. E. (1987), "Reliability-based optimization model for water distribution systems," J Hydraul Eng, 113(12), 1539-1556.

[5] Sevük A. S. \& Altınbilek D. (1977), Su Dağıtım Şebekleri Projelendirme ve Bilgisayarla Çözüm Esasları. Orta Doğu Teknik Üniversitesi.

[6] Schaake J. C. \& Lai F. H. (1969), Linear programming and dynamic programming application to water distribution network design. MIT Hydrodynamics Laboratory.

[7] Raad D.N. (2011), "Multi-objective optimisation of water distribution systems design using metaheuristics," Stellenbosch: University of Stellenbosch.

[8] Simpson A. R., Dandy G. C. \& Murphy L. J. (1994), "Genetic algorithms compared to other techniques for pipe optimization," J Water Res Plan Man, 120(4), 423-443.

[9] Dandy G. C., Simpson A. R. \& Murphy L. J. (1996), "An improved genetic algorithm for pipe network optimization," Water Resour Res, 32(2), 449-458.

[10]Savic D. A. \& Walters G. A. (1997), "Genetic algorithms for least-cost design of water distribution networks," J Water Res Plan Man, 123(2), 67-77.

[11]Wu Z.Y. \& Simpson A.R. (2001), "Competent geneticevolutionary optimization of water distribution systems," J Comput Civil Eng, 15(2), 89-101.

[12]Afshar M. (2005), "A convergent genetic algorithm for pipe network optimization," Sci Iran, 12(4).

[13]Özdağlar D., Benzeden E. \& Kahraman A.M. (2006), "Kompleks Su Dağıtım Şebekelerinin Genetik Algoritma ile
Optimizasyonu," Teknik Dergi, 17(82), 3851-3867.

[14]Kadu M.S., Gupta R. \& Bhave P.R. (2008), "Optimal design of water networks using a modified genetic algorithm with reduction in search space," J Water Res Plan Man, 134(2), 147-160.

[15] Conceicao Cunha M. \& Ribeiro L. (2004), "Tabu search algorithms for water network optimization," Eur J Oper Res, 157(3), 746-758.

[16]Suribabu C. and Neelakantan T. (2006), "Design of water distribution networks using particle swarm optimization," Urban Water J, 3(2), 111-120.

[17]Montalvo I., Izquierdo J., Pérez R. \& Tung M.M. (2008), "Particle swarm optimization applied to the design of water supply systems," Comput Math Appl, 56(3), 769-776.

[18] Ezzeldin R., Djebedjian B. \& Saafan T. (2013), "Integer discrete particle swarm optimization of water distribution networks," J Pipeline Syst Eng, 5(1), 04013013.

[19]Suribabu C. (2009), "Differential evolution algorithm for optimal design of water distribution networks," J Hydroinform, 12(1), 66-82.

[20]Vasan A. \& Simonovic S.P. (2010), "Optimization of water distribution network design using differential evolution," J Water Res Plan Man, 136(2), 279-287.

[21]Zheng F., Simpson A.R. \& Zecchin A. (2012), "A performance comparison of differential evolution and genetic algorithm variants applied to water distribution system optimization," in World Environmental and Water Resources Congress 2012: Crossing Boundaries, 2954-2963.

[22]Yılmaz V. (2015), "Su Dağıtım Şebekelerinin Metasezgisel Yöntemlerle Optimizasyonu," (yayımlanmamış doktora tezi) Selçuk Üniversitesi Fen Bilimleri Enstitüsü, Konya.

[23]Zeybekoğlu U. (2017), "Metasezgisel Optimizasyon Yöntemlerin Performanslarının Basit Bir Su Dağıtım Şebekesi Kullanılarak Araştırılması," Karadeniz Fen Bilimleri Dergisi, 7(2), 57-67.

[24] Noori M. (2021), "İnşaat projelerinde meta-sezgisel algoritmalar ile süre-maliyet-kalite ödünleşim problemlerinin optimizasyonu," Bursa Uludag University.

[25]Karpuzcu, M. (1985). Su temini ve çevre sağlı̆̆ı, Boğaziçi Üniversitesi.

[26]Cura, T. (2008). Modern sezgisel teknikler ve uygulamaları, Papatya Yayıncılık Eğitim.

[27]Karaboğa, D. (2004). "Yapay Zeka Optimizasyon Algoritmaları, Atlas Yayın Dağıtım, 1." Basım, İstanbul.

[28]Kaveh, A. and T. Bakhshpoori (2016). "A new metaheuristic for continuous structural optimization: water evaporation optimization." Structural and Multidisciplinary Optimization 54(1): 23-43.

[29]Öztürk, Ş., Yiğit, E., \& Özkaya, U. (2021). "Fused Deep Features Based Classification Framework for COVID-19 Classification with Optimized MLP." Konya Mühendislik Bilimleri Dergisi, 8, 15-27.

[30]Rashedi, E. (2009). "GSA: a gravitational search algorithm." Information sciences 179(13): 2232-2248.

[31]Selim, S. Z. \& Alsultan K. (1991). "A simulated annealing algorithm for the clustering problem." Pattern recognition 24(10): 1003-1008.

[32]Dorigo M. \& Stützle T. (2019). "Ant colony optimization: overview and recent advances." Handbook of metaheuristics: 311-351.

[33]Mareli M. \& Twala B. (2018). "An adaptive Cuckoo search algorithm for optimisation." Applied computing and informatics 14(2): 107-115. 